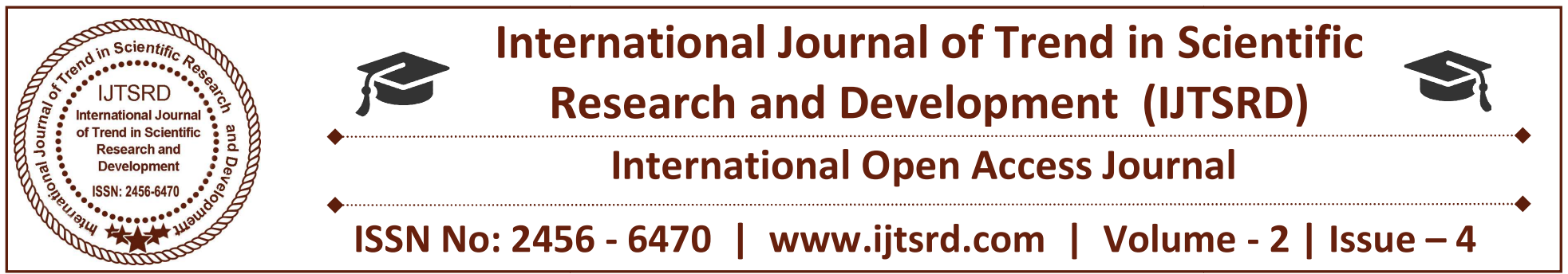

\title{
A New Weir Cum Causeway Design of Varachha Site under Surat Smart City Project
}

\author{
Shivam H. Joshi \\ Student, Department of Civil Engineering, MSCET (GTU), \\ Surat, Gujarat, India
}

\section{ABSTRACT}

Weir is a solid structure constructed across the river to raise the water level in the river flow. We proposed two sites: Amroli $(\mathrm{FRL}=4.0 \mathrm{~m})$ and Varachha (FRL $=4.0 \mathrm{~m} \& 5.0 \mathrm{~m})$. The maximum FRL of Varachha site has to be about $5.0 \mathrm{~m}$ used in design. We desired that the feasibility of keeping FRL 5.0 to get a water storage as well as wider and longer pond so, we selected Varachha site. We have selected L33-R33 section on river Tapi is safe for our design and no large afflux create on it. To calculated a design discharge and return period factor for 50 years for Varachha site. According to the model studies, the discharge 12,00,000 cusecs, 34000 TCM design given and calculate silt factor is 1.2 and the design discharge is 24,000 cumec. We given hydraulic design based on IS code 6966 (Part-1):1989 Hydraulic Design Of Barrages And Weirs-Guidelines. Weir length was $450 \mathrm{~m}$, crest level $8 \mathrm{~m}$, crest width $10 \mathrm{~m}$. We providing 16 nos. Of Automatic gates $(5 \times 3.5 \mathrm{~m})$. Hydraulic design given in two parts: (1)Floor Length Weir bays calculation and (2) Under sluice calculation 100\% discharge calculation considered as per IS code 6966 (Part-1):1989 calculated H.F.L 14.10m. The weir may be combined with a submersible bridge, it's solve a traffic of this Varachha site and to make ease of $24 \times 7$ potable drinking water for varachha region people. The water also available for industry uses and other activities.

Keywords: Hydraulic design, Tapi River, Varachha, Weir

\section{INTRODUCTION}

River Tapi is the $2^{\text {nd }}$ largest river of Gujarat State. It originates from Mulati, of Betul district of Madhya Pradesh; which includes $323 \mathrm{Km}$. from Maharashtra and $189 \mathrm{Km}$. from Gujarat. At present there are 37 major and minor bridges and two underpass ways in the city. Of them eight bridges are across River Tapi at various locations. Surat has been blessed with flow of river Tapi which fulfills most of its water requirements. It flows through city and meets Arabian Sea at about $16 \mathrm{Km}$. from Surat. Weir basically two purpose, (1)To provide a standing pool of water over infiltration wells (2) To provide a surface barrier to prevent tidal water from entering, infiltration well areas and also to provide a subsurface barrier to prevent subsurface saline water from entering infiltration well area.

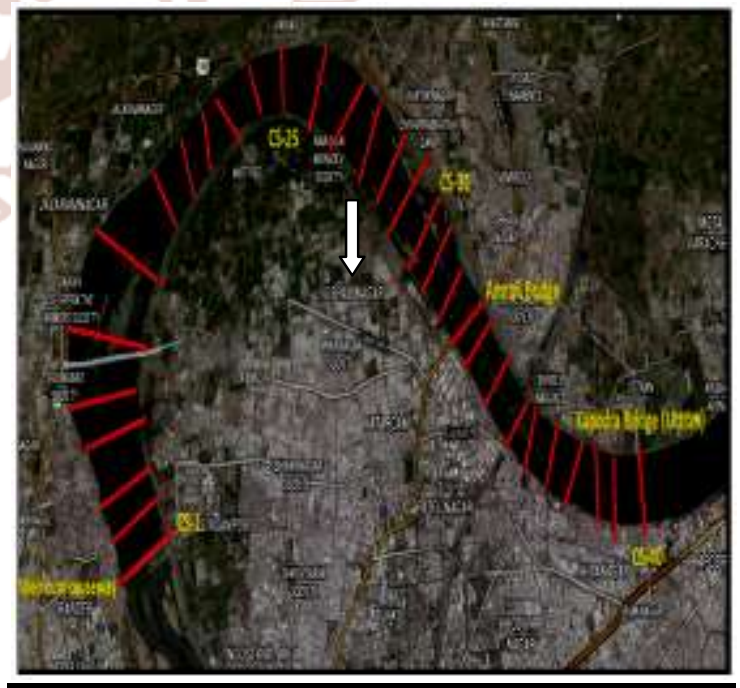

Figure 1: Study area with Cross-sections 
Source: Google Maps

\section{SITE SELECTION}

Varachha site is just downstream of infiltration wells. No industrial effluent of sewer line is connected upstream of this site. We desired that the feasibility of keeping FRL 5.0 to get a water storage as well as wider and longer pond so, we selected Varachha site. We have selected L33-R33 section on river Tapi is safe for our design and no large afflux create on it. The tail water ratings have been worked out using manning's equation

$$
\mathrm{V}=\frac{1}{N} \times \mathrm{R}^{2 / 3} \times \mathrm{S}^{1 / 2}
$$

Varachha sites as under Data used :

$\mathrm{n}=0.025$ for channel flow, $\mathrm{N}=0.06$ for banl flow, $S=1 / 5400$, Area $=$ as per survey section L33-L3: Retrogression level $=1.5 \mathrm{~m}$. The site at Varachha near th water works was preferred as the problem silting a varachha desired to be solved by providing an entirel: gated weir at river bed.

The site at amroli was not favoured as it did not provide a pond near city and has no special advantages.

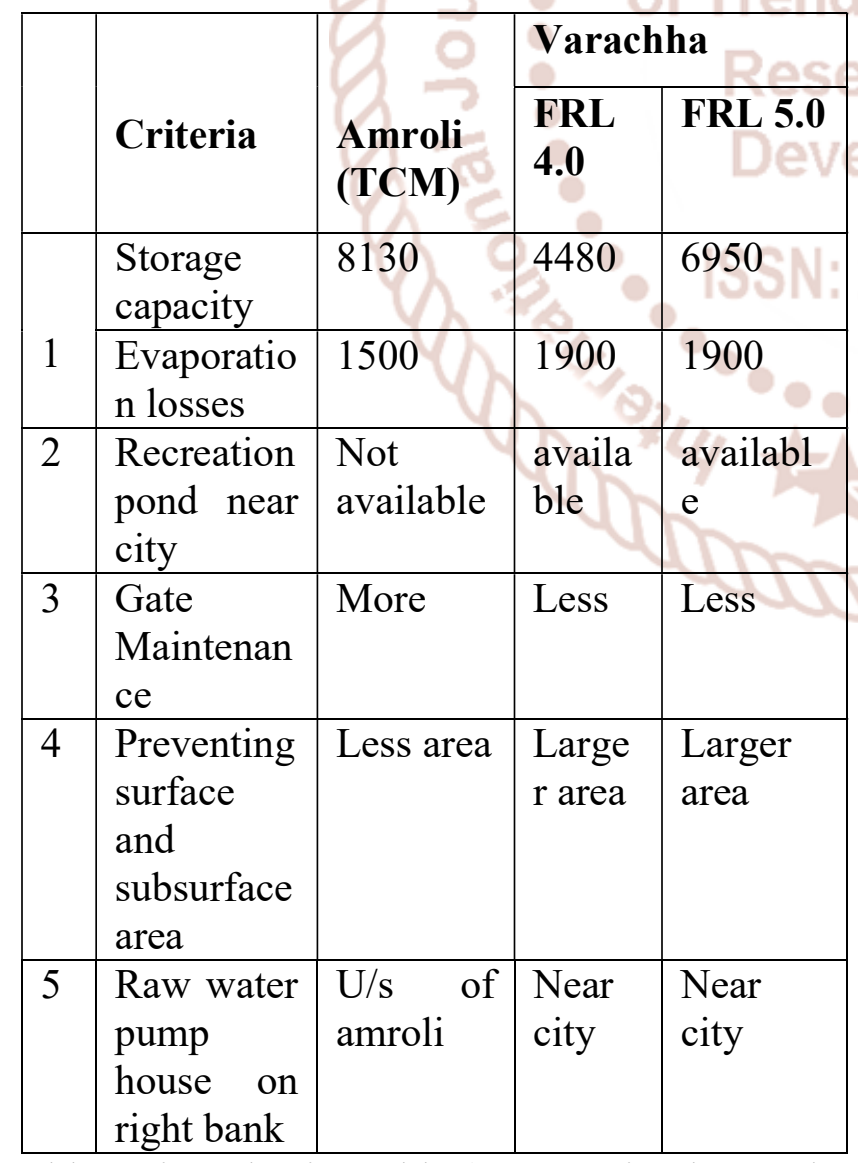

Table-1 site selection table (Evaporation losses data given by SMC \& Singanpore weir Model study report)

\section{TAIL WATER RATING CURVE}

Tail water rating curve is used to find TEL without retrogression and used value in hydraulic design,

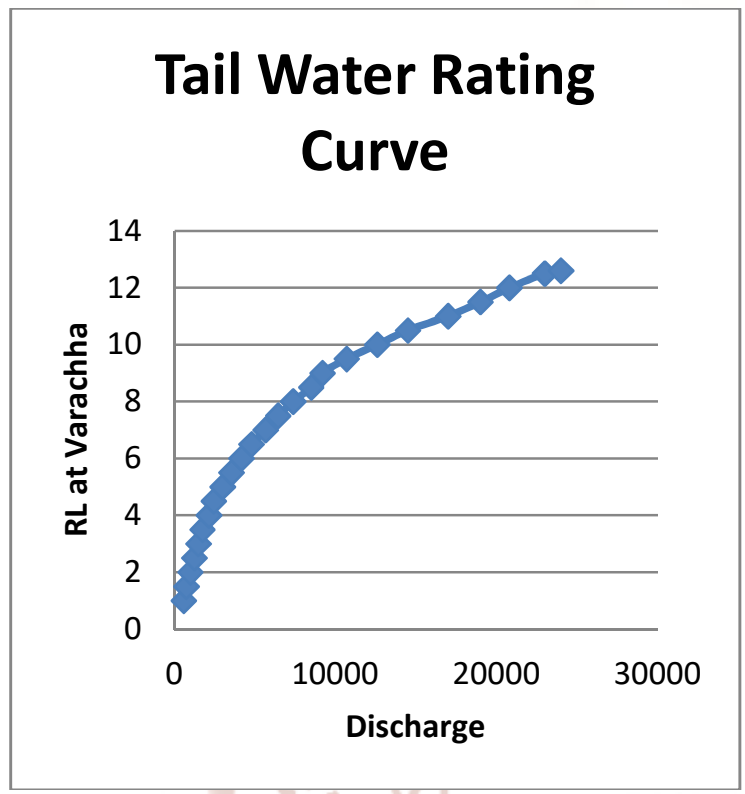

Fig 2: Varachha site tail water rating curve

\section{DESIGN PARAMETERS}

Following Factors are to be considered for our design: silt factor, Afflux, Design discharge, Waterway, Concentration factor etc.

FRL AND CREST LEVEL: The FRL is taken as R.L 5.0 and crest level $8.00 \mathrm{~m}$

DESIGN DISCHARGE: The design discharge is considered as $12,00,000$ Cusecs (i.e $34,000 \mathrm{~m}^{3} / \mathrm{s}$ as per model studies)

SILT FACTOR: The silt factor of 1.2 is used.

WEIR CREST: The weir crest is proposed $10 \mathrm{~m}$ wide to accommodate two lane traffic and a foot path as under

H.F.L: Afflux was determined by trial and error method using discharge coefficient $\mathrm{C}$ for submerged condition and using it's relation with,

\section{STEP FOR HFL CALCULATION}

\section{Step-1}

Drawing ratio $=\frac{\frac{\mathrm{D}}{\mathbf{s}} \text { water head-crest level }}{\frac{\mathrm{U}}{\mathrm{s}} \text { water head-crest level }}$ 
International Journal of Trend in Scientific Research and Development (IJTSRD) ISSN: 2456-6470 $=735 \mathrm{~m} \quad(\mathrm{~L}=$ weir length $=450 \mathrm{~m})$

$\underline{\text { Step-2 }}$ To find Velocity $\mathbf{V}=\mathbf{Q} / \mathbf{A}$

$\mathrm{H}=$ water head-crest $\mathrm{RL}$

$\mathrm{H}^{\prime}=\mathrm{H}+$ energy elevation

$\mathrm{Q}=\mathrm{CLH}^{3 / 2}$

Where,

$\mathrm{Q}=$ Discharge in cumec

$\mathrm{C}=$ Coefficient of discharge in free condition

$\mathrm{L}=$ Clear water way in metre

$\mathrm{H}=$ Head of over crest in metre

\section{HYDRAULIC DESIGN}

$100 \%$ calculation for design of weir bays \& Floor Length Weir Bays Calculation

\section{(1) Discharge cumec}

Unit discharge :

(A) Under sluice $Q_{1}=5000 \mathrm{cumec} / \mathrm{m}$

(B) Weir bays $\mathrm{Q}_{2}=20000$ cumec $/ \mathrm{m}$

(2) H.F.L.(U/S) computed $=14.10 \mathrm{~m}$

(3) TEL without retrogression $=12.60 \mathrm{~m}$

(4)T.E.L due to retrogression $=12.10 \mathrm{~m}$

(5)Unit Discharge q on weir $=44 \mathrm{cumecs} / \mathrm{m}$

$\frac{Q}{L}=\frac{20000}{450}=44.44$ take $44 \mathrm{cumecs} / \mathrm{m}$

(Take weir length $=\mathrm{L}=450 \mathrm{~m}$ )

$10 \%$ concentration factor computed in H.F.L $=1.1 \times 44=44.44$

$20 \%$ concentration factor computed in H.F.L $=1.2 \times 44=52.8$

take 53 cumecs $/ \mathrm{m}$

(6) Loosness factor $=\mathrm{L} / \mathrm{R}<1$

(when looseness factor is less than 1)

$$
=450 / 735=0.61<1
$$

$\mathrm{R}=$ regime perimeter $=475(\mathrm{q})^{0.5}$

$=475 \times(24000)^{0.5}$
(7) Scour depth $\mathbf{R}=1.35\left(\mathrm{q}^{2} / \mathrm{f}\right)^{0.33}$

Where,

$\mathrm{R}=$ depth of scour below the highest flood level in $\mathrm{m}$; $\mathrm{Q}=$ his flood discharge in the river in ; $\mathrm{f}=$ silt factor $=1.76 \frac{q}{f}$ $\mathrm{q}=$ intensity of flood discharge in $\mathrm{m}^{3} / \mathrm{s}$ per $\mathrm{m}$ width.

Scour depth $\mathrm{R}=1.35\left(\mathrm{q}^{2} / \mathrm{f}\right)^{0.33}$

$$
=1.35\left(44^{2} / 1.2\right)^{0.33}
$$

$$
=15.44 \text { say } 16 \mathrm{~m}
$$

(8) $\mathrm{U} / \mathrm{s}$ floor level $=1.5 \mathrm{~m}$

(9) Depth of flow ' $D$ ' (U/S) =

$$
(14.1-1.5)=12.6 \mathrm{~m}
$$

Depth of flow 'D' $(\mathrm{D} / \mathrm{S})=$ $(12.6-1.5)=11.1 \mathrm{~m}$

(10) Velocity of Approach (U/S)=

$$
\mathrm{V}_{\mathrm{a}}=\mathrm{q} / \mathrm{D}=\frac{24000 / 450}{12.6}=4.23 \mathrm{~m} / \mathrm{s}
$$

Velocity of Approach $(\mathrm{D} / \mathrm{S})=$

$$
\mathrm{V}_{\mathrm{a}}=\mathrm{q} / \mathrm{D}=\frac{24000 / 450}{11.1}=4.80 \mathrm{~m} / \mathrm{s}
$$

\section{(11) Velocity Head}

$$
\mathrm{H}_{\mathrm{a}}=\mathrm{Va}^{2} / 2 \mathrm{~g}(\mathrm{U} / \mathrm{s})=0.91 \mathrm{~m}
$$

$\frac{4.23 \times .23}{2 \times 9.81}=0.91 \mathrm{~m}$

$$
\text { Velocity Head }
$$

$$
\mathrm{H}_{\mathrm{a}}=\mathrm{Va}^{2} / 2 \mathrm{~g}(\mathrm{D} / \mathrm{s})=1.17 \mathrm{~m}
$$

$$
\frac{4.80 \times 4.80}{2 \times 9.81}=1.17 \mathrm{~m}
$$

(12)T.E.L (U/S) $=\operatorname{col}(2)+\operatorname{col}(11)(\mathrm{U} / \mathrm{S})$

$$
\begin{aligned}
& =14.10+0.91 \\
& =15.01 \mathrm{~m}
\end{aligned}
$$

(13) T.E.L (D/S) $=\operatorname{col}(3)+\operatorname{col}(11)(\mathrm{D} / \mathrm{S})$ 
International Journal of Trend in Scientific Research and Development (IJTSRD) ISSN: 2456-6470

$$
\begin{aligned}
& =12.6+1.17 \\
& =13.77 \mathrm{~m}
\end{aligned}
$$

(14) Head Loss 'H' $=\operatorname{col}(12)-\operatorname{col}(13)=1.24 \mathrm{~m}$

\section{(15) Find Discharge}

For ' $\mathrm{q}$ '=53 Cumecs $/ \mathrm{m}$ (As per Central Design Organisation Gandhinagar that $10 \%$ concentration of flow should be allowed for river Tapi)

$\mathrm{D}=2 \mathrm{R}$ scour depth

$$
\mathrm{R}=1.35\left(\mathrm{q}^{2} / \mathrm{f}\right)^{0.33}=15.44 \times 2=30.88 \text { say } 30
$$

Conjugate depths from equation=

$\left(\mathrm{D}_{2}-\mathrm{D}_{1}\right)^{3} / 4 \mathrm{D}_{1} \mathrm{D}_{2}=\mathrm{H}_{\mathrm{L}}=\frac{(\mathrm{D} 2-\mathrm{D} 1)^{\wedge} 0.33}{4 \mathrm{D} 1 \mathrm{D} 2}$
$\mathrm{D}_{1} \mathrm{D}_{2}\left(\mathrm{D}_{1}+\mathrm{D}_{2}\right)=2 \mathrm{q}^{2} / \mathrm{g}$

$\mathrm{D}_{2}=8.47 \mathrm{~m}$ and $\mathrm{D}_{1}=3.8 \mathrm{~m}$

(16) Tail water Depth $=\operatorname{col}(3)-\operatorname{col}(8)=(12.6-1.5)=$ $11.1 \mathrm{~m} / \mathrm{s}$

$\mathrm{D}_{2}<$ Tail water level, there is no possibility of formation of Hydraulic jump

(17) Velocity at $D_{1}$

$$
\mathrm{V}_{1}=\frac{q}{\mathrm{D} 1}=\frac{44}{3.8}=11.57 \mathrm{~m} / \mathrm{s}
$$

(18) Froude no. $=\mathrm{v}_{1} /\left(\mathrm{gD}_{1}\right)^{1 / 2}$

$$
=(11.57) /(9.81 \times 3.8)^{\wedge} 0.5
$$

$$
=1.894<2.00
$$

\section{CONCLUSION}

As there is no large afflux created on selected L33 and $\mathrm{R} 33$ section on river Tapi which is safe for our design. According to discharge of $12,00,000$ cusecs, the design discharge and silt factor $=1.2$, has been calculated and safe site for it is Varachha site. We have given hydraulic design based on IS code 6966 (Part-1):1989 Hydraulic Design Of Barrages and Weirs-Guidelines. We designed a hydraulic design for Varachha site and to check all parameters affected on it.

\section{REERENCES}

1) IS code 6966 (Part-1):1989 Hydraulic Design Of Barrages And Weirs-Guidelines

2) Charles Rickard, Rodney Day, Jeremy Purseglove, "River Weirs - Good Practice Guide - Section A" R\&D Publication W5B-023/HQP October 2003

3) N. Narayana Pillai, Arun Goel, and Ashoke Kumar Dubey. "Hydraulic jump type stilling basin for low froude numbers" Journal of hydraulic engineering ASCE 1989.

4) Hermann M. Fritzi and Willi H. Hager. "Hydraulics Of Embankment Weirs" Journal of hydraulic engineering ASCE 1998. 